\title{
Raymond Trousson, Diderot jour après jour. Chronologie
}

\section{Franco Piva}

\section{Q OpenEdition}

1 Journals

\section{Edizione digitale}

URL: http://journals.openedition.org/studifrancesi/27617

DOI: 10.4000/studifrancesi.27617

ISSN: 2421-5856

\section{Editore}

Rosenberg \& Sellier

\section{Edizione cartacea}

Data di pubblicazione: 31 décembre 2006

Paginazione: 607

ISSN: 0039-2944

\section{Notizia bibliografica digitale}

Franco Piva, «Raymond Trousson, Diderot jour après jour. Chronologie », Studi Francesi [Online], 150 (L | III) | 2006, online dal 30 novembre 2015, consultato il 08 novembre 2020. URL : http:// journals.openedition.org/studifrancesi/27617; DOI : https://doi.org/10.4000/studifrancesi.27617

Questo documento è stato generato automaticamente il 8 novembre 2020.

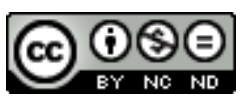

Studi Francesi è distribuita con Licenza Creative Commons Attribuzione - Non commerciale - Non opere derivate 4.0 Internazionale. 


\title{
Raymond Trousson, Diderot jour après jour. Chronologie
}

\author{
Franco Piva
}

\section{NOTIZIA}

RAYMOND TROUSSON, Diderot jour après jour. Chronologie, Paris, Honoré Champion, 2006

(«Les Dix-huitièmes siècles», 101), pp. 231.

1 Ricostruire la cronologia di Diderot non è impresa facile: a differenza di Rousseau, che ha lasciato degli scritti autobiografici in grado di offrire indicazioni di prima mano, o di Voltaire, di cui ci è rimasta una corrispondenza mastodontica dalla quale è stato, tutto sommato, agevole trarre le indicazioni utili alla ricostruzione della sua cronologia, Diderot non ci ha lasciato scritti autobiografici significativi, e di lui ci è rimasta una corrispondenza troppo parziale per essere di valido aiuto. Per ricostruirne una cronologia quanto più possibile completa, Raymond Trousson ha quindi dovuto ricorrere a testimonianze soprattutto esterne, quelle appunto che potevano recare, per esempio. l'autobiografia di Rousseau, che di Diderot è stato, come è noto, amico fraterno per molti anni, e la corrispondenza di Voltaire, oltre, altrettanto naturalmente, a quella di Rousseau e di altri scrittori dell'epoca. Ne è uscita una cronologia che se non è altrettanto completa di quella messa a punto a proposito di Voltaire e di Rousseau, non potrà tuttavia non riuscire di notevole utilità a quanti al direttore dell'Encyclopédie e all'autore di Jacques le Fataliste si accosteranno: tanto per la datazione di alcune delle sue opere, quanto per l'indicazione dei fatti più salienti della sua travagliata, e per certi aspetti ancora poco conosciuta esistenza. Un altro prezioso strumento, ad ogni modo, per accostarsi ad un uomo e ad uno scrittore certamente tra i più significativi, anche se ancora tra i più sfuggenti, di quel secolo dei Lumi, di cui è stato uno dei più interessanti protagonisti. 